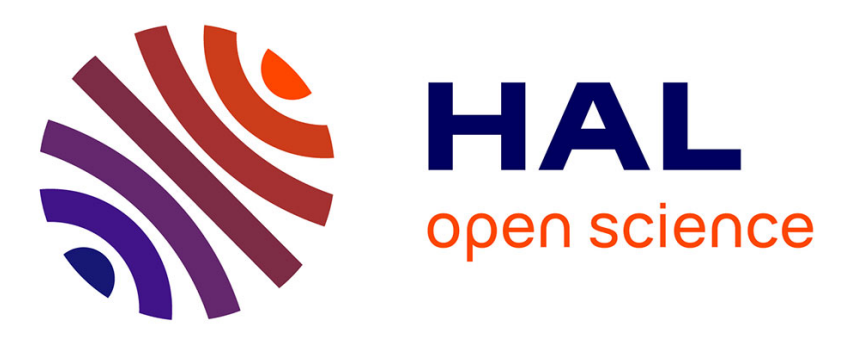

\title{
Height of faceted spurs, a proxy for determining long-term throw rates on normal faults: Evidence from the North Baikal Rift System, Siberia
}

Carole Petit, Bertrand Meyer, Yanni Gunnell, Marc Jolivet, Vladimir A. San'Kov, Vincent Strak, Nahossio Gonga-Saholiariliva

\section{To cite this version:}

Carole Petit, Bertrand Meyer, Yanni Gunnell, Marc Jolivet, Vladimir A. San'Kov, et al.. Height of faceted spurs, a proxy for determining long-term throw rates on normal faults: Evidence from the North Baikal Rift System, Siberia. Tectonics, 2009, 28, pp.TC6010. 10.1029/2009TC002555. hal-00455985

\section{HAL Id: hal-00455985 \\ https://hal.science/hal-00455985}

Submitted on 30 Apr 2021

HAL is a multi-disciplinary open access archive for the deposit and dissemination of scientific research documents, whether they are published or not. The documents may come from teaching and research institutions in France or abroad, or from public or private research centers.
L'archive ouverte pluridisciplinaire HAL, est destinée au dépôt et à la diffusion de documents scientifiques de niveau recherche, publiés ou non, émanant des établissements d'enseignement et de recherche français ou étrangers, des laboratoires publics ou privés. 


\title{
Height of faceted spurs, a proxy for determining long-term throw rates on normal faults: Evidence from the North Baikal Rift System, Siberia
}

\author{
Carole Petit, ${ }^{1}$ Bertrand Meyer, ${ }^{1}$ Yanni Gunnell, ${ }^{2}$ Marc Jolivet, ${ }^{3,4}$ Vladimir San'kov, ${ }^{5}$ \\ Vincent Strak, ${ }^{1}$ and Nahossio Gonga-Saholiariliva ${ }^{2}$ \\ Received 12 June 2009; revised 4 September 2009; accepted 21 September 2009; published 24 December 2009.
}

[1] We present new results on the long-term throw rates of active normal faults in the North Baikal Rift (NBR), eastern Siberia, based on a statistical analysis of triangular faceted scarps. Fault-bounded ridges in the NBR display typical morphologies with several contiguous facets separated by fault-perpendicular catchments. Over a range of 20 fault segments analyzed, triangular facet heights vary from $\sim 200$ to $>900 \mathrm{~m}$. As fault scarps have been developing under similar long-term climatic conditions, we infer that the scatter in mean facet height arises from long-term differences in fault throw rate. We compare the morphology of NBR facets with results obtained in a previously published numerical model of facet growth. Using facet height as an input, model results provide estimates of the long-term fault throw rate. NBR throw rates vary between 0.2 and $1.2 \mathrm{~mm} \mathrm{yr}^{-1}$. The throw rates are then compared with the cumulated throw, which has been constrained by geophysical and stratigraphic data in the basins. This provides an estimate of the age of fault and basin initiation. We show that the modern stage of basin development started circa $3 \mathrm{Myr}$ ago, except for the North Baikal basin $(\sim 8 \mathrm{Ma})$. Our results also suggest that a proportion of the observed throw is inherited from an earlier tectonic stage. Citation: Petit, C., B. Meyer, Y. Gunnell, M. Jolivet, V. San'kov, V. Strak, and N. Gonga-Saholiariliva (2009), Height of faceted spurs, a proxy for determining long-term throw rates on normal faults: Evidence from the North Baikal Rift System, Siberia, Tectonics, 28, TC6010, doi:10.1029/2009TC002555.

\section{Introduction}

[2] In continental active tectonics settings, determining the long-term slip rate of individual faults is a crucial step toward an improved understanding of the dynamics of deformation.

\footnotetext{
${ }^{1}$ ISTEP, UMR 7193, UMPC Université Paris 6, CNRS, Paris, France.

${ }^{2}$ Laboratoire de Géographie Physique, UMR 8591, Université Paris VII, CNRS, Paris, France.

${ }^{3}$ Géosciences Montpellier, UMR 5243, Université Montpellier 2, CNRS, Montpellier, France.

${ }^{4}$ Now at Géosciences Rennes, UMR 6118, Université de Rennes 1, CNRS, Rennes, France.

${ }^{5}$ Institute of the Earth's Crust, Russian Academy of Sciences, Irkutsk, Russia.

Copyright 2009 by the American Geophysical Union. 0278-7407/09/2009TC002555
}

However, direct measurements of slip rates are often scant because the number of well-dated offset features is limited along a given fault trace.

[3] Horizontal offsets of dated terraces, alluvial fans, or moraines have long been used for determining slip rates on large strike-slip faults [e.g., Ritz et al., 1995; Brown et al., 1998; Kozaci et al., 2007; Weldon and Sieh, 1985; van der Woerd et al., 2006; Meyer and Le Dortz, 2007]. Such horizontal offsets seldom span a time period larger than $300 \mathrm{kyr}$, and their dating, either by radiocarbon isotopes or by the in situ production of cosmogenic nuclides, requires extensive sampling in the field.

[4] Offset geomorphic markers have also been used to derive the slip rates of active normal and thrust faults. However, because of the erosional response of rivers and hillslopes to relief growth, passive markers are often poorly preserved. In such rapidly eroding landscapes, the kinetics of tectonic processes can instead be interpreted from fluvial or hypsometric signatures. For example, the shape of river-long profiles crossing active fault zones can be used to assess changes in footwall uplift rates [Carretier et al., 2006; Attal et al., 2008; Cowie et al., 2008]. Given that river channels are assumed to attain an equilibrium profile when tectonic and erosion processes balance each other out, any departure from such a concave-up longitudinal profile, for example, a broad, convex-up knick zone, could suggest disequilibrium between tectonic processes and fluvial response [Whittaker et al., 2008]. Finally, low-temperature thermochronology, which provides exhumation rates of samples for the uppermost kilometers of the crust, is also used as a proxy for block uplift rates, provided the geothermal gradient can be estimated [Armstrong et al., 2004]. On the condition that evolving scarp face morphologies can be appropriately dated, the geometry of active markers can therefore be used to infer the rate of tectonic processes in many settings.

[5] Petit et al. [2009] used a 2.5-D tectonic and surface process model to explore the influence of tectonic attributes (fault throw rate and dip angle) and erosional parameters (diffusion and incision rates) on the development of faceted spurs at normal fault scarps. They showed that, provided erosional conditions were suitable for the development of triangular faceted spurs rather than any other range front morphology, mean facet height was a linear function of the vertical fault throw rate. By virtue of this simple relationship, from a population of triangular facets along a fault or a population of range-bounding faults it should be possible to determine not only (1) the long-term averaged throw rate of 


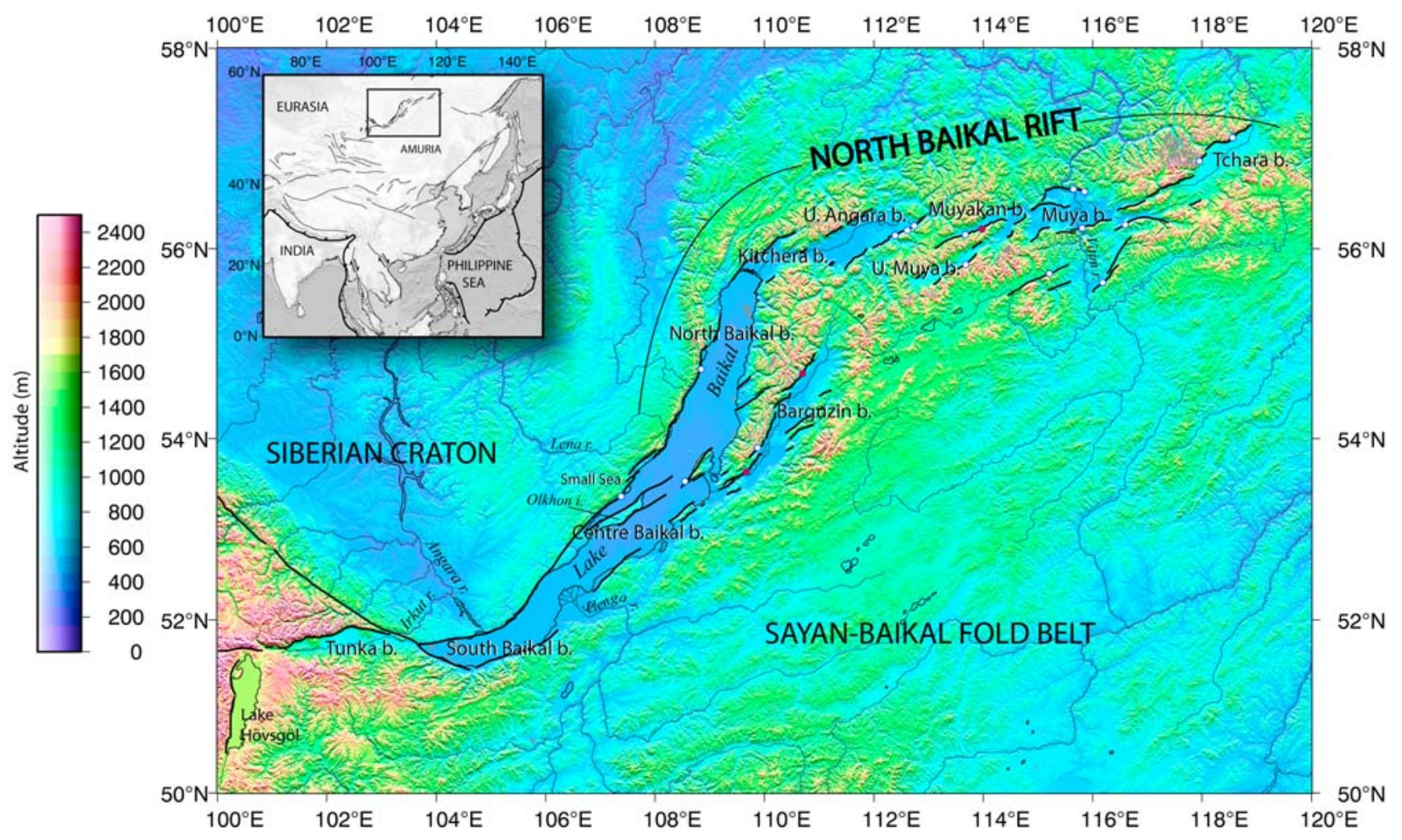

Figure 1. Topography, active faults, and basins of the North Baikal Rift. Basin names after Logatchev and Zorin [1992] and San'kov et al. [2000]. Open dots indicate locations where faceted spurs have been measured; red dots correspond to the images shown in Figure 2. Main river names are indicated. Inset shows the location of the study region in the tectonic framework of Asia.

active normal fault segments but also (2) the age of the footwall basin, i.e., the age of the main fault.

[6] In this paper, we present new results on the long-term throw rates of active faults in the North Baikal Rift (NBR), in southeastern Siberia, from a statistical analysis of triangular facets. Fault throw rates are then compared to the cumulated throw, which is constrained by geophysical and stratigraphic data in the rift basins. This in turn allows us to provide an estimate of the age of fault and basin initiation.

\section{Baikal Rift System: Geologic Setting and Kinematics}

[7] The Baikal Rift System (BRS) is located in northeast Asia, north of the India-Asia collision zone (Figure 1) [Petit and Déverchère, 2006, Figure 1]. It extends over $\sim 1500 \mathrm{~km}$ in a $\sim \mathrm{SW}-\mathrm{NE}$ direction and consists of several basins of different ages and geometries [e.g., Logatchev and Florensov, 1978]. It extends to the NE along the Stanovoy strike-slip zone [Parfenov et al., 1987], and in the SW it links up with the left-lateral strike-slip fault system of western Mongolia [e.g., Cunningham, 2001]. From a kinematic point of view, the BRS is part of the western boundary of the Amurian (or North China) plate, which has been moving eastward with respect to Eurasia at a rate of less than $1 \mathrm{~cm} \mathrm{yr}^{-1}$ [e.g., Calais et al., 2003; Petit and Fournier, 2005]. Whereas the southern half of the BRS is characterized by very localized deformation and forms a unique, deep, and elongated basin, the North Baikal Rift displays a succession of smaller en echelon basins over a rift width almost 3 times as large as the southern half (Figure 1).

[8] The age of the onset of rifting in the BRS is difficult to determine. Early deposits dated as Late Cretaceous to Eocene on the basis of lithostratigraphic arguments [Mats, 1993] occur locally in the southern part of the rift, but they are not considered to be rift deposits [Kashik and Masilov, 1994]. More widespread deposits typical of shallow basins are dated around $\sim 27 \mathrm{Ma}$ (i.e., late Oligocene) in the southern and central parts. Basins of the NBR probably formed later, i.e., mostly during Pliocene times [e.g., Hutchinson et al., 1992].

[9] Recent GPS data indicate that the southern Baikal Rift is opening at a rate of $4 \pm 1 \mathrm{~mm} \mathrm{yr}^{-1}$ in a NW-SE direction in response to the counterclockwise rotation of Amuria with respect to Eurasia around a pole located north of the Stanovoy region [Calais et al., 2003]. The slip rates on individual faults of the Baikal Rift are not obtainable from these data. Field measurements of deformed postglacial terraces in the NBR have allowed San'kov et al. [2000] to infer Holocene fault slip rates ranging between 0.5 and $2 \mathrm{~mm} \mathrm{yr}^{-1}$ and mean rift initiation ages of 1.1-6.6 Myr. However, their results based on of precise radiocarbon ages are only relevant to the Muya basin (Figure 1), and furthermore, Holocene slip rates 

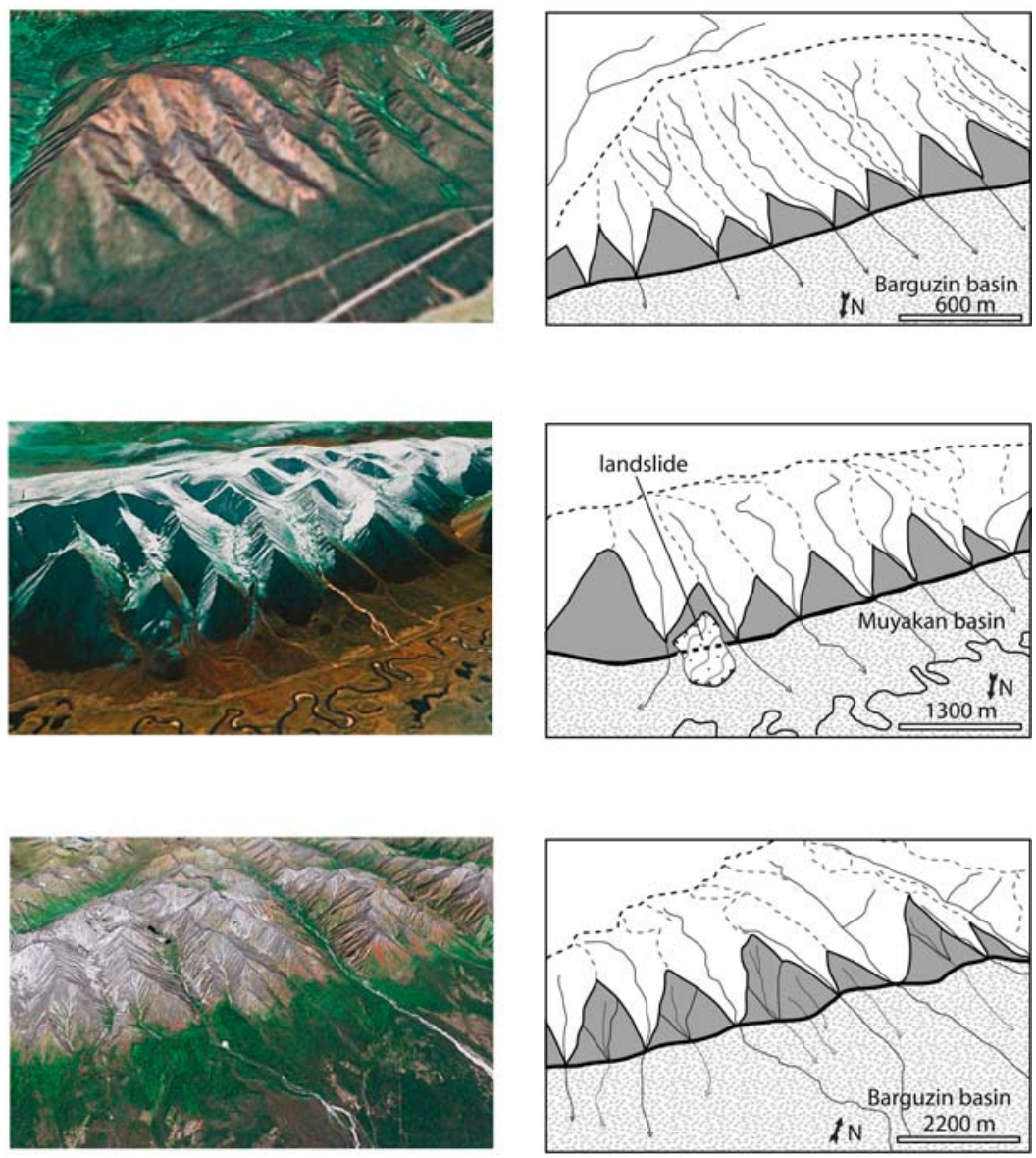

Figure 2. Oblique views of three triangular facet-bearing scarps of the North Baikal Rift in the (top) south Barguzin, (middle) Muyakan, and (bottom) north Barguzin basins. Google Earth imagery (C) Google Inc. Used with permission.

may not accurately represent longer-term $(\sim 1 \mathrm{Myr})$ fault velocities.

[10] Fault-bounded mountain ridges in the NBR typically display a well-delineated fault line, several contiguous facets exhibiting similar morphologies separated by faultperpendicular catchments, and a main drainage divide trending on average parallel to the fault scarp (Figure 2). One feature of note is that, depending on the fault segment, triangular facet height varies widely (Figure 2), with measured values ranging between $\sim 200$ and $>900 \mathrm{~m}$. The larger triangular facets sometimes display imbrication features due to the persistence of small fault-perpendicular catchments on the facet slope (Figure 2) [e.g., Ellis et al., 1999; Petit et al., 2009]. Assuming that all of these North Baikal faceted scarps have been developing under similar long-term climatic conditions, we infer that differences in mean faceted spur height from one fault segment to another arise primarily as a result of differences in long-term fault throw rate rather than local variations in total runoff. Footwall lithology is fairly uniform (Table 1), mainly consisting of granites and gneisses [Malitch, 1999]. The bedrock is, therefore, dominated by crystalline and metamorphic rocks that are resistant to erosion. One exception is the Small Sea escarpment (Figure 1) which has formed in Proterozoic marbles.

\section{Faceted Spur Characteristics and Comparison With Numerical Model Predictions}

[11] We measured facet height and slope on 106 triangular facets belonging to 20 fault segments in the NBR (i.e., about 5 facets per fault segment) using the $90 \mathrm{~m}$ Shuttle Radar Topography Mission (SRTM) database (Table 1). On the resulting digital elevation model (DEM), facet height is defined as the local relief between the scarp base and the upper vertex of the triangle. Mean facet slope is the slope of the triangle's altitude measured between the base and the vertex. The fault segments were selected according to the following criteria: eligible segments should (1) exhibit at least four contiguous triangular facets with similar morphologies and heights greater than $150 \mathrm{~m},(2)$ show no evidence of massive landsliding on the faceted scarp faces, and (3) lack strong facet imbrication. In the case of moderate facet imbrication, the largest facet dimensions were chosen. The Kitchera and northern Upper Angara basins, for example, did 
Table 1. Name, Bedrock Type, Geographical Location, Number of Measured Facets, and Mean Facet Height and Slopes of the North Baikal Rift

\begin{tabular}{|c|c|c|c|c|c|c|c|c|}
\hline \multirow[b]{2}{*}{ Fault/Basin Name } & \multirow[b]{2}{*}{ Bedrock Type $^{a}$} & \multicolumn{2}{|c|}{ Segment Midpoint } & \multirow[b]{2}{*}{ Number of Facets } & \multicolumn{2}{|c|}{ Facet Height (m) } & \multicolumn{2}{|c|}{ Facet Slope (deg) } \\
\hline & & Latitude $\left({ }^{\circ} \mathrm{N}\right)$ & Longitude $\left({ }^{\circ} \mathrm{E}\right)$ & & Average & SD & Average & SD \\
\hline Small Sea & marble & 53.3579 & 107.3160 & 8 & 384 & 51 & 26 & 3 \\
\hline North Baikal 1 & gneiss & 53.5585 & 108.5903 & 6 & 535 & 87 & 34 & 2 \\
\hline Barguzin 1 & granite & 53.6397 & 109.6518 & 7 & 181 & 42 & 23 & 3 \\
\hline Barguzin 2 & granite & 54.2382 & 110.1931 & 5 & 847 & 102 & 37 & 4 \\
\hline Barguzin 3 & granite & 54.6361 & 110.6000 & 5 & 891 & 125 & 35 & 3 \\
\hline North Baikal 2 & gneiss & 54.7290 & 108.8000 & 4 & 513 & 78 & 28 & 2 \\
\hline Tundak & gneiss & 55.6679 & 116.2186 & 5 & 272 & 36 & 22 & 3 \\
\hline Tsipa-Baunt & granite & 55.7447 & 115.2457 & 4 & 397 & 26 & 23 & 3 \\
\hline Upper Muya & granite & 55.8519 & 113.7190 & 4 & 428 & 34 & 31 & 4 \\
\hline Upper Angara 1 & granite & 56.1415 & 112.4851 & 5 & 421 & 84 & 29 & 2 \\
\hline Muyakan 1 & granite & 56.1500 & 113.7426 & 5 & 610 & 60 & 33 & 3 \\
\hline Upper Angara 2 & granite & 56.1968 & 112.6954 & 5 & 410 & 60 & 26 & 3 \\
\hline Muyakan 2 & granite & 56.2101 & 114.0133 & 4 & 782 & 125 & 36 & 6 \\
\hline South Muya & gneiss & 56.2240 & 115.8746 & 7 & 461 & 94 & 29 & 4 \\
\hline Upper Angara 3 & granite & 56.2663 & 112.8651 & 5 & 534 & 79 & 31 & 3 \\
\hline Namarakit & gneiss & 56.2586 & 116.6856 & 6 & 540 & 92 & 34 & 1 \\
\hline North Muya 1 & metabasite & 56.6106 & 115.6228 & 4 & 246 & 7 & 23 & 1 \\
\hline North Muya 2 & metabasite & 56.5986 & 115.7824 & 5 & 517 & 41 & 34 & 2 \\
\hline Tchara 1 & granite & 56.8415 & 117.9317 & 5 & 652 & 91 & 35 & 4 \\
\hline Tchara 2 & gneiss & 57.0043 & 118.2786 & 7 & 725 & 86 & 35 & 3 \\
\hline
\end{tabular}

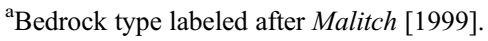

not satisfy these criteria. Facet morphometric attributes were then compared to the results of numerical models obtained by Petit et al. [2009], which predict throw rate as a linear function of facet height.

\subsection{Numerical Model}

[12] The generic model incorporates long-scale fluvial erosion and short-scale diffusion on a regular $100 \times 100 \mathrm{~m}$ grid, inspired by previous formulations by Braun and Sambridge [1997] and Kooi and Beaumont [1994].

[13] Hillslope transport is modeled using a linear diffusion law where the rate of erosion is linearly related to the curvature of the topographic slope:

$$
\frac{\partial h}{\partial t}=K_{D} \Delta h
$$

where $h$ is topographic elevation, $t$ is time, and $K_{D}$ is the diffusion coefficient. Mass conservation is observed by the computation of the diffusive flux, $\mathbf{q}_{\mathbf{D}}$ :

$$
\mathbf{q}_{\mathbf{D}}=-K_{D} \operatorname{grad}(h)
$$

The diffusion coefficient is artificially increased when local slope exceeds a threshold angle of $40^{\circ}$ in order to simulate conditions relevant to landsliding. The diffusion equation is solved using an explicit finite difference approximation.

[14] Fluvial erosion is simulated by using over the entire grid a uniform effective precipitation rate, $v_{r}$, which is the proportion of rainfall that effectively contributes to runoff, and a linear stream power law in which the equilibrium sediment flux is proportional to river discharge and to local topographic slope:

$$
q_{e q}=K_{f} q_{r} \frac{\partial h}{\partial l}
$$

where $q_{e q}$ is the equilibrium flux, or carrying capacity of the river; $K_{f}$ is a transport coefficient; $q_{r}$ is the local water discharge; and $\partial h / \partial l$ is local slope in the stream direction. Local discharge is computed by integrating upstream precipitation on the principle that each grid cell transfers all of its surface water to only one of its eight neighbors in the direction of maximum slope using the D8 method of $O$ 'Callaghan and Mark [1984]. The rate of incision depends on the imbalance between carrying capacity, $q_{e q}$, and the local sediment flux, $q_{f}$, generated by erosion upstream:

$$
\frac{\partial h}{\partial t}=\left(q_{f}-q_{e q}\right) / w L_{f}
$$

where $w$ is a unit channel width and $L_{f}$ is a characteristic transport length that depends on the detachability of channel bed materials [e.g., Kooi and Beaumont, 1994]. If net sediment flux exceeds carrying capacity, $L_{f}$ decreases to allow rapid deposition of excess sediments. $L_{f}$ is a model erosion parameter input and classically varies from 10 to $20 \mathrm{~km}$ (for highly erodible bedrock) to more than $100 \mathrm{~km}$ (in the case of poorly erodible bedrock) [e.g., Kooi and Beaumont, 1994].

[15] Faulting occurs at regular time intervals and progressively deforms the surface topography. Surface deformation is modeled in three dimensions by a kinematic model on the basis of the planar elastic dislocation solution of Okada 
[1985]. The magnitude of coseismic slip and time recurrence of earthquakes are adjusted to fit the required fault slip rate. The grid is deformed by repeated earthquakes. In order to maintain a good spatial resolution on the fault scarp and to avoid biases due to uneven grid spacing, regular remeshing was performed by adding a line of nodes on the fault scarp whenever the cumulative horizontal displacement equaled the original grid spacing (here $0.1 \mathrm{~km}$ ). Given the short length scales of the Baikal footwall blocks, flexural isostatic response to erosion and sedimentation is not included in our model.

[16] Petit et al. [2009] first demonstrated that faceted spurs can develop under a given range of erosional conditions (defined by the amount of runoff and substratum erodibility) characterized by a balance between diffusion and incision. Out of these conditions, nonfaceted escarpments are observed and correspond either to nonincised (sharp or rounded) escarpments or to escarpments that are totally destroyed by erosion. They then tested the influence of tectonic parameters (fault dip angle and slip rate) on the shape of triangular facets. Fault dip angle was left to vary from $30^{\circ}$ to $75^{\circ}$ and the total fault slip rate from 0.25 to $1.5 \mathrm{~mm} \mathrm{yr}^{-1}$, all such changes producing different throw rates as a function of dip angle. Three different erosional parameter sets were tested $\left(K_{D}=\right.$ $0.05 \mathrm{~m}^{2} \mathrm{yr}^{-1}, v_{r}=1 \mathrm{~m} \mathrm{yr}^{-1}$, and $L_{f}=10 \mathrm{~km} ; K_{D}=0.05 \mathrm{~m}^{2}$ $\mathrm{yr}^{-1}, v_{r}=1 \mathrm{~m} \mathrm{yr}^{-1}$, and $L_{f}=20 \mathrm{~km}$; and $K_{D}=0.1 \mathrm{~m}^{2} \mathrm{yr}^{-1}, v_{r}=$ $1 \mathrm{~m} \mathrm{yr}^{-1}$ and $L_{f}=20 \mathrm{~km}$ ). Mean facet height and mean facet slope were measured in the way indicated earlier in this section for the Baikal spurs.

[17] On the basis of these numerical results, we computed a relationship between throw rate and facet height using the facet height values measured for each input throw rate and constrained by the three previously defined erosional parameter sets (Figure 3a). Uncertainty is defined as the standard deviation of facet height measurements. Figure 3 a shows that the linear correlation between facet height and fault throw rate is very good $\left(R^{2}=0.94\right)$ and predicts that the fault throw rate in $\mathrm{mm} \mathrm{yr}^{-1}$ should be equal to 0.0013 times the mean facet height, in meters.

[18] Numerical models also predict a linear relationship between facet slope and fault throw rate, and the relationship is not sensitive to the erosion parameters chosen, provided they are compatible with the development of faceted spurs [see Petit et al., 2009]. Within the bracket of erosional conditions favorable to faceted spur development, steady state facet height is reached when the vertical erosion rate is high enough to balance out the tectonic uplift rate. Within this range of favorable erosional conditions, the time needed to reach steady state is remarkably constant (about $1 \mathrm{Myr}$ ) whatever the erosion parameters. Therefore, the facet height primarily depends on the vertical uplift rate.

[19] It follows that a linear correlation between facet height and facet slope (Figure 3b) also exists, which predicts that when facet height increases by $100 \mathrm{~m}$, facet slope increases by about $4^{\circ}$. In Figures $3 b$ and $3 c$, the intercept with the $y$ axis is not equal to zero because even for low throw rates faceted spurs occur with a minimum threshold slope of $\sim 5^{\circ}-10^{\circ}$. As a consequence, in every active normal fault setting where well-developed triangular faceted spurs are observed, it is expected that facet height $(H)$ can be used to predict the throw rate $\left(S_{v}\right)$ of active faults using the following equation:

$$
S_{v}=0.0013 H
$$

on the condition that the relationship between the observed facet slope angle $(\alpha)$ and facet height satisfies

$$
d \alpha / d H \sim 0.04
$$

\subsection{Results From the North Baikal Rift}

[20] Mean facet heights and facet slopes measured in the North Baikal Rift display considerable variation, with ranges of $200-900 \mathrm{~m}$ and $22^{\circ}-38^{\circ}$, respectively (Figure 3c). In addition, the facet slope to facet height relationship is consistent with the results obtained with the numerical model (compare Figure $3 \mathrm{~b}$ ), although the $y$ axis intercept here is $\sim 11^{\circ}$ instead of $\sim 5^{\circ}$. We interpret this intercept value as a minimum slope threshold condition under which faceted scarp faces are created, even in the case of infinitesimally small fault throw rates. It probably reflects rock mass strength properties, i.e., bedrock resistance to slope decline as a result of erosion processes, and hence may take on a range of values depending on lithology and structure. For slope angles greater than $\sim 35^{\circ}-38^{\circ}$, the linear relationship observed between facet height and slopes breaks down, probably because higher slopes exceed the rock stability threshold and landsliding occurs. When a landslide occurs on the faceted scarp face, the new landslide headscarp displaces the fault scarp face back from the fault line, but its altitude differs little from its prelandslide value. Landslides should, therefore, dominantly affect mean facet slope, leaving facet height almost unchanged. On the basis of the empirical linear relationship described in equation (5), we conclude that mean facet heights of the NBR can be used as quantitative proxies of the long-term fault throw rates.

\section{Fault Velocities, Cumulated Throw, and Basin Ages}

[21] Calculated throw rates vary between 0.2 and $1.2 \mathrm{~mm}$ $\mathrm{yr}^{-1}$, with upper-range values occurring in the Barguzin basin (Table 2 and Figure 4). Other fault segments have a throw rate of $0.5 \pm 0.2 \mathrm{~mm} \mathrm{yr}^{-1}$, except in the Muyakan and Tchara basins, where throw rates reach $0.9 \pm 0.1 \mathrm{~mm}$ $\mathrm{yr}^{-1}$. These values are lower than the Holocene throw rates estimated by radiometric dating of alluvial terraces by San'kov et al. [2000], which vary between 0.5 and $2.1 \mathrm{~mm} \mathrm{yr}^{-1}$.

[22] In order to examine in what proportion the presentday topography of the NBR is related to recent fault activity, we compared the previously determined fault throw rates with the apparent and total cumulated throws. Apparent throw is defined here as the relative relief between the footwall mountain crest and the topographic basin floor (or bottom of the lake in the case of submerged Lake Baikal basins), and total cumulated throw is the difference in altitude 
Numerical modelling inferences (Petit et al., 2009)
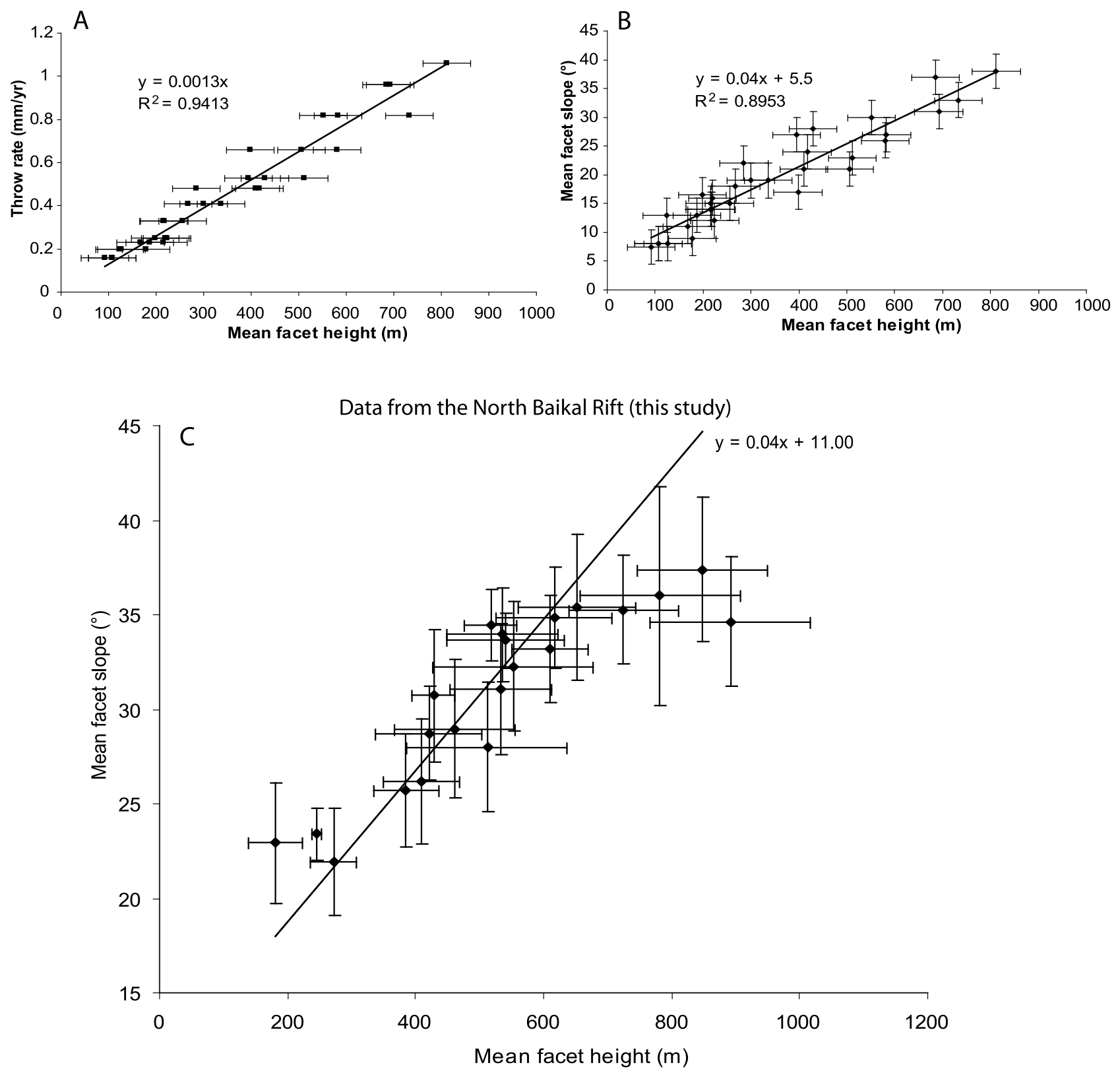

Figure 3. Statistical relationships between triangular facet attributes and tectonic variables in numerical modeling and field settings. Results of numerical models of triangular facet formation after Petit et al. [2009]: (a) mean fault throw rate as a function of facet height and (b) mean facet height as a function of facet slope. (c) Results of triangular facet measurements in the North Baikal Rift (this study). A line with slope equal to the one deduced from numerical models (but with a different $y$ axis intercept) is shown for comparison.

between the footwall mountain crest and the sedimentary basin floor. Four fault-perpendicular topographic profiles were drawn for each of the 20 studied fault segments, allowing uncertainty on apparent throws to be estimated (Figure 5). Basement depths were extracted from previously published sediment isobaths by Logatchev and Zorin [1992] on the basis of gravity data and borehole drillings in the different rift basins.
[23] Results show that apparent throw is linearly correlated with the fault throw rates (Figure 6a and Table 2), with the smallest values of $\sim 800 \mathrm{~m}$ for throw rates of $\sim 0.2 \mathrm{~mm} \mathrm{yr}^{-1}$ and apparent throws as large as $\sim 1700 \mathrm{~m}$ for throw rates of $\sim 1.2 \mathrm{~mm} \mathrm{yr}^{-1}$. Total cumulated throws also appear rather well correlated with fault throw rates, except for the two points of the North Baikal basin (Figure 6b), which display a much larger throw than expected by the regression model 
Table 2. Inferred Throw Rate, Apparent Throw, and Total Throw

\begin{tabular}{|c|c|c|c|c|c|c|}
\hline \multirow[b]{2}{*}{ Fault/Basin Name } & \multicolumn{2}{|c|}{ Throw Rate $\left(\mathrm{mm} \mathrm{yr}^{-1}\right)$} & \multirow{2}{*}{$\begin{array}{l}\text { Apparent Throw } \\
\text { (m) }\end{array}$} & \multirow{2}{*}{$\begin{array}{l}\text { Sediment Thickness } \\
\text { (m) }\end{array}$} & \multicolumn{2}{|c|}{ Total Throw ${ }^{\mathrm{a}}(\mathrm{m})$} \\
\hline & Average & SD & & & Average & SD \\
\hline Small Sea & 0.50 & 0.1 & 960 & 1250 & 2210 & 50 \\
\hline North Baikal 1 & 0.70 & 0.1 & 1430 & 4000 & 5430 & 100 \\
\hline Barguzin 1 & 0.24 & 0.1 & 750 & 500 & 1250 & 50 \\
\hline Barguzin 2 & 1.10 & 0.1 & 1665 & 2000 & 3665 & 100 \\
\hline Barguzin 3 & 1.16 & 0.2 & 1730 & 2000 & 3730 & 150 \\
\hline North Baikal 2 & 0.67 & 0.1 & 1490 & 4000 & 5490 & 100 \\
\hline Tundak & 0.35 & 0.1 & 1060 & $\mathrm{ND}^{\mathrm{b}}$ & ND & ND \\
\hline Tsipa-Baunt & 0.52 & 0.1 & 920 & 500 & 1420 & 100 \\
\hline Upper Muya & 0.56 & 0.1 & 1280 & 1000 & 2280 & 150 \\
\hline Upper Angara 1 & 0.55 & 0.1 & 1255 & 1000 & 2255 & 100 \\
\hline Muyakan 1 & 0.79 & 0.1 & 1310 & 1000 & 2310 & 100 \\
\hline Upper Angara 2 & 0.53 & 0.1 & 1115 & 1100 & 2210 & 100 \\
\hline Muyakan 2 & 1.02 & 0.1 & 1505 & 1500 & 3005 & 50 \\
\hline South Muya & 0.60 & 0.1 & 1205 & 500 & 1705 & 50 \\
\hline Upper Angara 3 & 0.69 & 0.1 & 1265 & 1000 & 2265 & 50 \\
\hline Namarakit & 0.70 & 0.1 & 1300 & ND & ND & ND \\
\hline North Muya 1 & 0.67 & 0.1 & 1300 & 500 & 1800 & 50 \\
\hline North Muya 2 & 0.32 & 0.2 & 840 & 500 & 1340 & 20 \\
\hline Tchara 1 & 0.85 & 0.1 & 1000 & 1490 & 2490 & 150 \\
\hline Tchara 2 & 0.94 & 0.1 & 1350 & 1590 & 2940 & 100 \\
\hline
\end{tabular}

${ }^{a}$ Total throw is the sum of apparent throw (see text and Figure 5 for explanation) and sediment thickness [Logatchev and Zorin, 1992].

${ }^{\mathrm{b}} \mathrm{ND}$, no data.

(i.e., $\sim 5500 \mathrm{~m}$ instead of $\sim 2500 \mathrm{~m}$ ). The linear correlation between cumulated throws and throw rates obtained for the studied sample of NBR basins suggests that these basins started to develop at approximately the same time. The mean age of rift initiation, in kyr, is given by the slope of the total throw versus throw rate regression model. In Figure $6 \mathrm{~b}$, the linear regression line was obtained with all data points except the two North Baikal ones and assuming that the $y$ axis intercept was zero, i.e., that no altitude difference existed between the footwall and the hanging wall when facet development began. Under this assumption, the mean age of the North Baikal Rift basins is $~ 3.2$ Myr. Taking into account data point dispersal around this line, we can bracket this age between 2.8 and 4.5 Myr (Figure 6b), indicating that

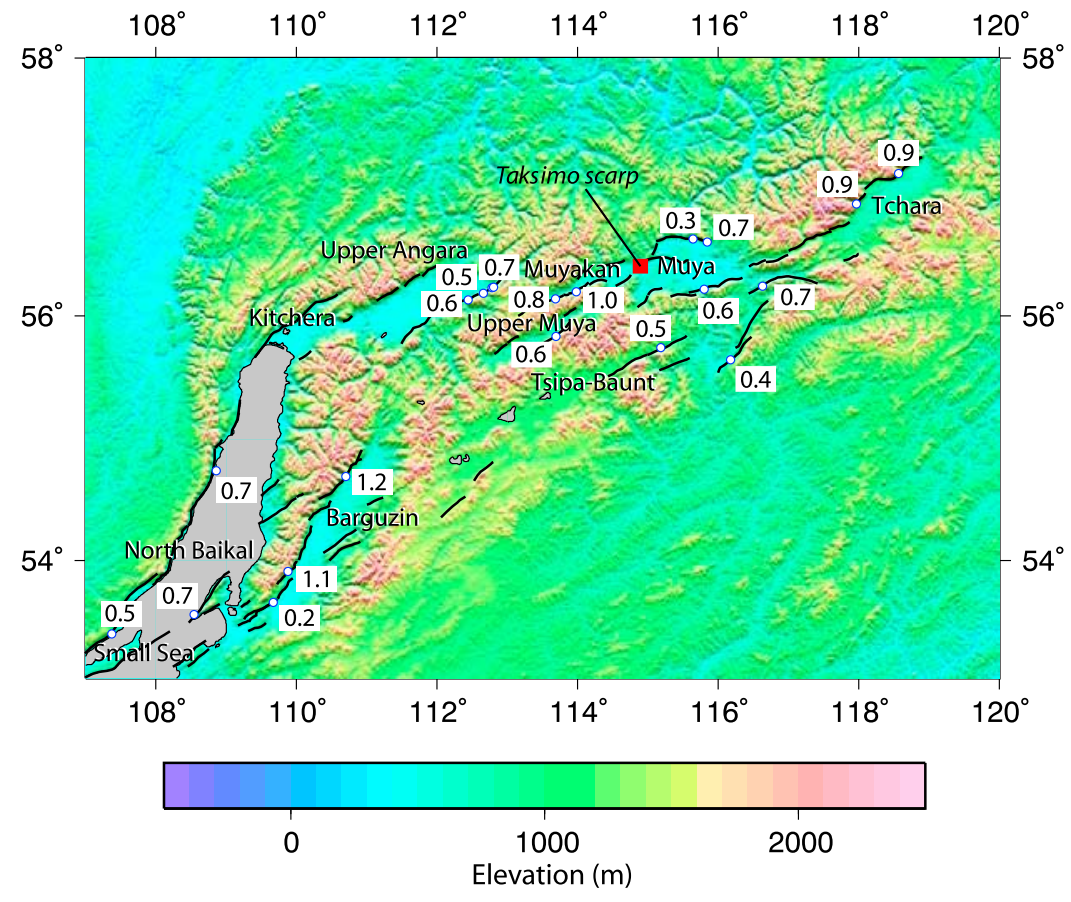

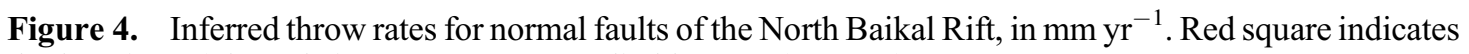
the location of the Taksimo escarpment studied by San'kov et al. [2000]. 

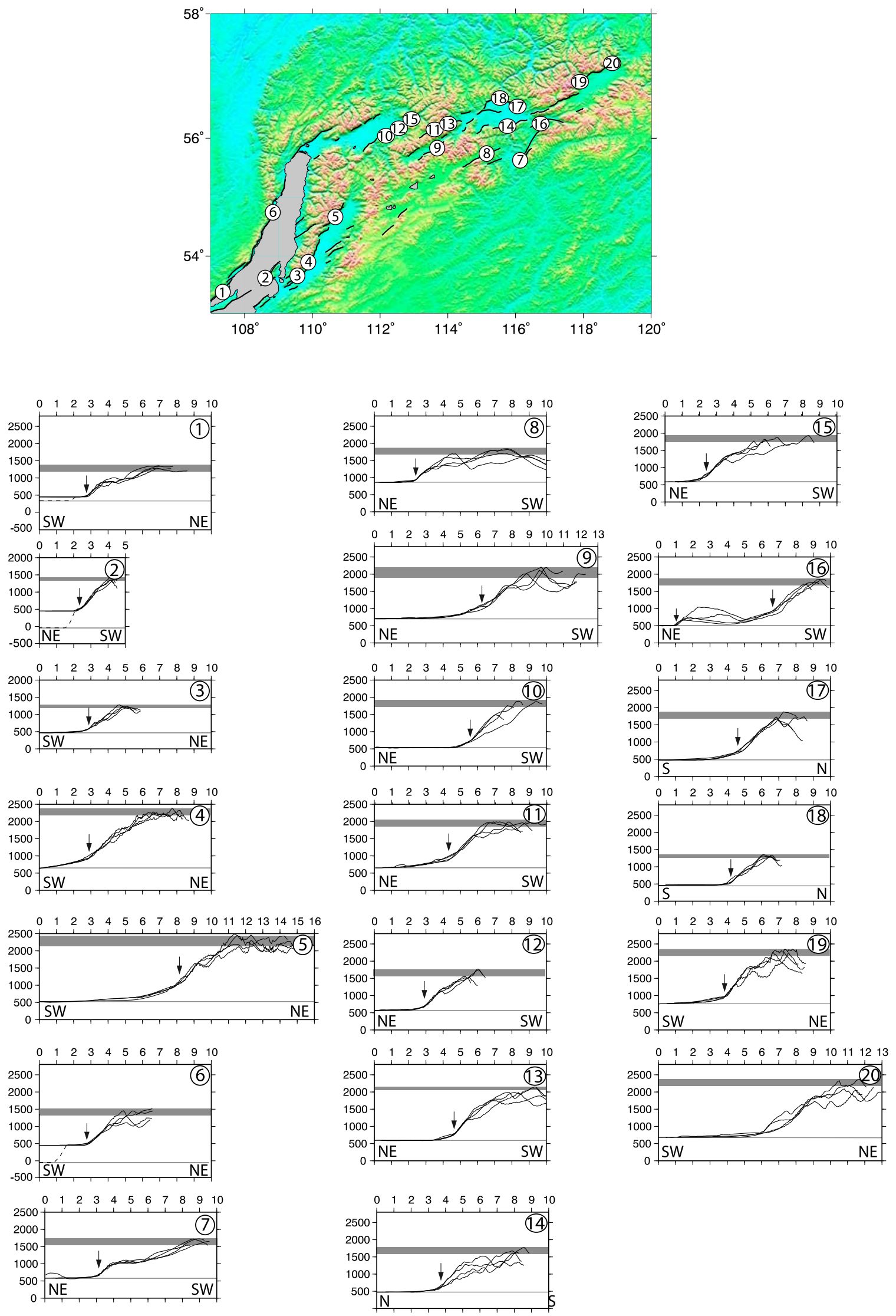

Figure 5

8 of 12 

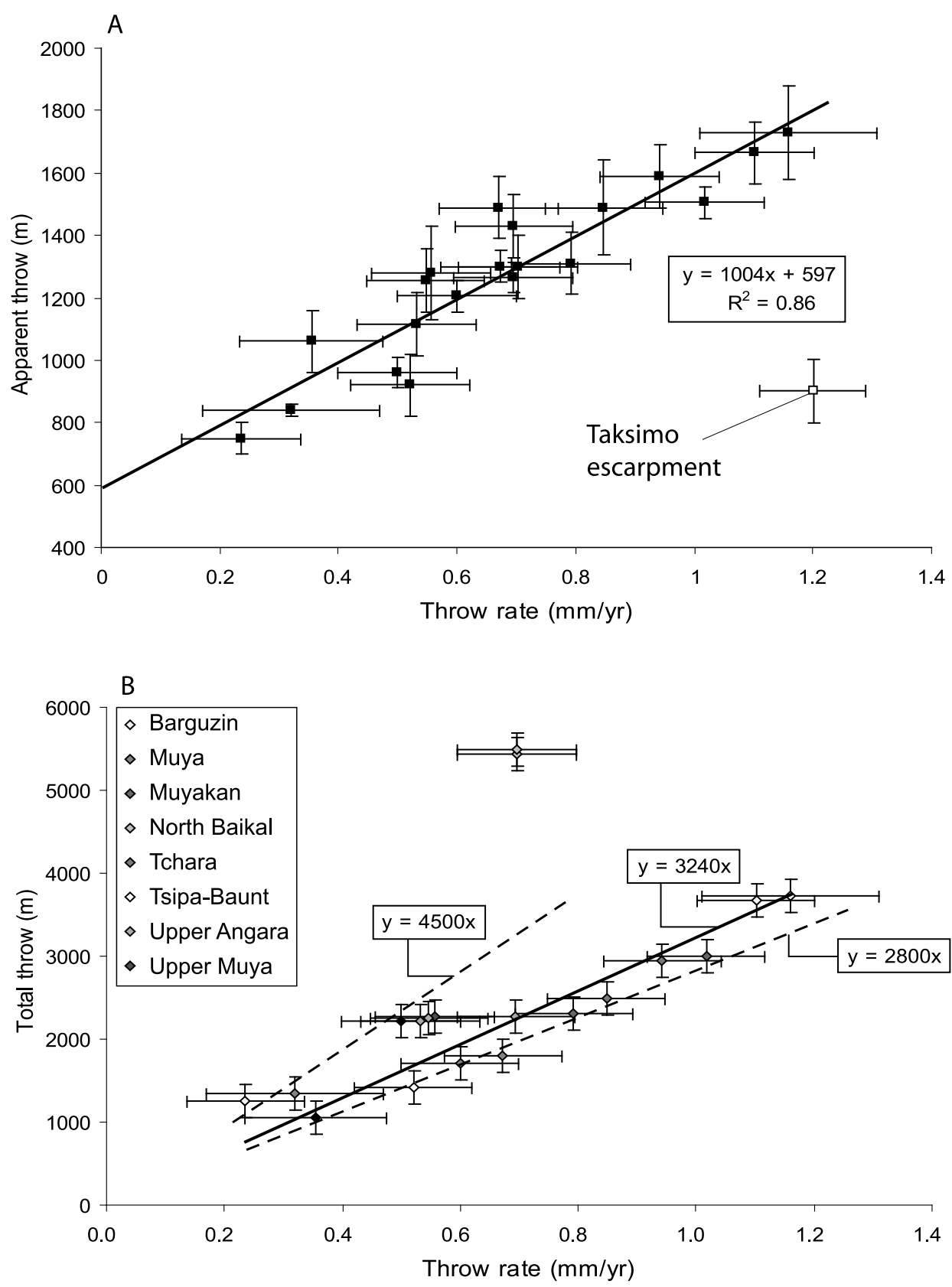

Figure 6. Statistical relationships between scarp height, current basin depth, and fault throw rate. (a) Relationship between apparent fault throw and mean throw rate for North Baikal basins, with corresponding uncertainties. The open square corresponds to the apparent throw measured at the Taksimo escarpment combined with the Holocene throw rate after San 'kov et al. [2000]. (b) Relationship between total throw and throw rate. The solid line is the best fitting regression line for all data points except those of the North Baikal basin. Dashed lines show two end-member slopes that bracket the full set of observations.

Figure 5. Topographic profiles used for estimating apparent throw at a range of NBR normal fault scarps. Apparent throw is defined here as the difference between the highest points of the footwall and hanging wall (see text). Solid arrow indicates the location of the fault trace at the surface. Grey bands correspond to the range of altitudes (with estimated uncertainties) used to compute the throw. Numbers refer to basin names indicated in Tables 1-4: 1, Small Sea; 2, North Baikal 1; 3, Barguzin 1; 4, Barguzin 2; 5, Barguzin 3; 6, North Baikal 2; 7, Tundak; 8, Tsipa-Baunt; 9, Upper Muya; 10, Upper Angara 1; 11, Muyakan 1; 12, Upper Angara 2; 13, Muyakan 2; 14, South Muya; 15, Upper Angara 3; 16, Namarakit; 17, North Muya 1; 18, North Muya 2; 19, Tchara 1;20, Tchara 2. 
Table 3. Basin Name and Age Estimates

\begin{tabular}{lcccc}
\hline \multicolumn{1}{c}{ Basin } & $\begin{array}{c}\text { Age 1 } \\
(\mathrm{Myr})\end{array}$ & $\begin{array}{c}\text { Number of } \\
\text { Points }\end{array}$ & $\begin{array}{c}y \text { Axis Intercept } \\
(\mathrm{m})\end{array}$ & $\begin{array}{c}\text { Age 2 } \\
(\mathrm{Myr})\end{array}$ \\
\hline Barguzin & 2.7 & 3 & 610 & 4.0 \\
Muyakan & 3.1 & 2 & -151 & 2.9 \\
North Baikal & & & & 7.8 \\
Muya & 1.3 & 3 & 923 & 3.2 \\
Tchara & & & & 2.9 \\
Tsipa-Baunt & & & & 2.7 \\
Upper Muya & & & 752 & 3.1 \\
Upper Angara & 2.7 & 2 & & 3.8 \\
\hline
\end{tabular}

${ }^{\mathrm{a}} \mathrm{Age} 1$ corresponds to the slope of the linear regression line where several throw rate points are available. Number of points is shown in the third column.

${ }^{\mathrm{b}} \mathrm{Age} 2$ is the age deduced from one or several throw rate points assuming a null $y$ axis intercept value for the throw versus throw rate regression model.

the population of NBR basins began to form during Pliocene time.

[24] The age of individual basins is more difficult to determine: when several data points are available for a single basin, departures from zero of the throw versus throw rate line may occur on the $y$ axis intercept, implying that a proportion of the total throw is inherited from an earlier tectonic phase during which faceted spurs were either not generated or were subsequently eroded (age 1 taking into account inherited relief in Table 3 ). When only one throw rate data point is available, we must assume a null $y$ axis intercept. This can also apply for basins with several data points (age 2 assuming null inherited relief in Table 3). Only four basins of the North Baikal Rift have more than one throw rate data point (Barguzin, Muya, Muyakan, and Upper Angara; see Table 3). Whatever the method chosen, all basins produce estimated ages ranging between 1 and 4 Myr. The age of the Barguzin basin varies between 2.7 and $4 \mathrm{Myr}$, with, for the younger age estimate, an inherited throw of $\sim 600 \mathrm{~m}$ and of unknown age. The two points of the Muyakan basin yield an unlikely negative $y$ axis intercept value. The second age estimate for Muyakan (2.9 Myr) is therefore preferred even though it is not significantly different from the first one
(3.1 Myr). A large difference between age 1 and age 2 is observed for the Muya basin (1.3 and 3.2 Myr), with a $y$ axis intercept of $923 \mathrm{~m}$ for the 1.3 Myr age estimate. Finally, the Upper Angara basin has similar age estimates as the Barguzin basin, i.e., 2.7 Myr for age 1 and 3.8 Myr for age 2. Among basins with only one throw rate data point, the North Baikal basin is the only one showing a Miocene age (7.8 Myr), which explains why its two points fall well above the linear trend shown in Figure $6 \mathrm{~b}$.

\section{Discussion}

[25] Long-term throw rates obtained here can be compared with those estimated in the region for the Holocene by San 'kov et al. [2000]. Our results predict throw rates that are, on average, lower than the Holocene estimates, except for the Barguzin fault (Table 4). The difference in fault throw rates exceeds the sum of uncertainty estimates for the North Baikal 2, Tsipa-Baunt, South Muya, Upper Angara 2, and North Muya 1 faults. For some of those faults, Holocene estimates are much higher than long-term ones (Table 4). Two factors could explain this discrepancy.

[26] 1. The fault throw rate may not be steady and could vary on timescales of several thousands of years, in which case the detected differences are real rather than methodrelated artifacts. This aspect cannot, however, be resolved by our numerical modeling method.

[27] 2. Some of the results of San 'kov et al. [2000] could be biased because of a possible misinterpretation of the age of alluvial terraces, which was ascribed as a function of their altitude by correlation with dated alluvial terraces along the Taksimo escarpment bounding the west side of the Muya basin (Figure 4). Unfortunately, the Taksimo fault scarp could not be used to infer the long-term fault throw rate because it bounds a very narrow mountain ridge with short $(1-2 \mathrm{~km}$ long) fault-perpendicular catchments that do not meet the criteria of steady state range fronts selected for this study.

[28] Age estimates published by San'kov et al. [2000] predict a late Miocene age for the North Baikal and Barguzin basins and a mid-Pliocene age for all other basins except the Muya, which is supposed to be of Pleistocene age. Our results

Table 4. Comparison Between Throw Rate and Basin Age Estimated in This Study and by San'kov et al. [2000]

\begin{tabular}{|c|c|c|c|c|c|c|c|}
\hline \multirow[b]{3}{*}{ Fault/Basin Name } & \multicolumn{4}{|c|}{ Throw Rate $\left(\mathrm{mm} \mathrm{yr}^{-1}\right)$} & \multicolumn{3}{|c|}{ Basin Age (Myr) } \\
\hline & \multicolumn{2}{|c|}{ This Study } & \multicolumn{2}{|c|}{ San'kov et al. [2000] } & \multirow[b]{2}{*}{ Age 1} & \multirow[b]{2}{*}{ Age 2} & \multirow[b]{2}{*}{ San'kov et al. [2000] } \\
\hline & Average & SD & Average & SD & & & \\
\hline North Baikal 1 & 0.70 & 0.10 & 1.00 & 0.20 & & 7.8 & 6.1 \\
\hline North Baikal 2 & 0.67 & 0.10 & 1.00 & 0.20 & & 7.8 & 6.1 \\
\hline Barguzin 2 & 1.10 & 0.10 & 1.00 & 0.20 & 2.7 & 4.0 & 6.0 \\
\hline Tsipa-Baunt & 0.52 & 0.10 & 1.30 & 0.20 & & 2.7 & 1.0 \\
\hline Upper Muya & 0.56 & 0.10 & 0.70 & 0.10 & & 4.1 & 3.0 \\
\hline Muyakan 1 & 0.79 & 0.10 & 0.80 & 0.10 & 3.1 & 2.9 & 2.5 \\
\hline Muyakan 2 & 1.02 & 0.10 & 0.70 & 0.10 & 3.1 & 2.9 & 2.5 \\
\hline South Muya & 0.60 & 0.10 & 2.10 & 0.20 & 1.3 & 3.2 & 1.1 \\
\hline Upper Angara 3 & 0.69 & 0.10 & 1.50 & 0.20 & 2.7 & 3.8 & 4.1 \\
\hline North Muya 1 & 0.67 & 0.10 & 1.60 & 0.20 & 1.3 & 3.2 & 1.1 \\
\hline Tchara 2 & 0.94 & 0.10 & 1.00 & 0.20 & & 2.9 & 3.2 \\
\hline
\end{tabular}


are rather consistent with those estimates (i.e., within less than 2 Myr), except for the Barguzin and Tsipa-Baunt basins, for which San'kov et al. [2000] obtained larger and smaller ages, respectively.

[29] The history of basin formation inferred from this study is consistent with the late Miocene to Pliocene development of the North Baikal Rift that has been independently obtained from stratigraphy and basin analysis [e.g., Hutchinson et al., 1992; Logatchev and Zorin, 1992] and from seismic studies [Hutchinson et al., 1992; Moore et al., 1997]. All reveal a major unconformity dated at $\sim 7 \mathrm{Ma}$, which correlates with a regional unconformity that has been more widely detected in the sedimentary sequence of Lake Baikal. Another discontinuity is documented around 2.6 Ma [Kuzmin et al., 2000], which suitably matches the mean age of basin initiation in the North Baikal Rift.

[30] Finally, our age and throw rate estimates can be compared with apatite fission track data in the Barguzin basin. Ten samples collected from the fault line to the mountain crest on the western edge of that basin allowed Jolivet et al. [2009] to model the cooling history of the footwall. Cooling models are characterized by a first Late Cretaceous to Paleocene slow cooling phase, followed by a period of quiescence and a second phase of rapid denudation starting in early Pliocene time $(5 \pm 2 \mathrm{Ma})$ and spanning $\sim 60^{\circ} \mathrm{C}$ of cooling. Considering a mean surface heat flow of $60 \mathrm{~mW} \mathrm{~m}^{-2}$ [Lysak, 1978] and a thermal conductivity for the continental crust of $2.5 \mathrm{~W} \mathrm{~m}^{-1} \mathrm{~K}^{-1}$, this magnitude of recent cooling corresponds to a denudation of $\sim 2.5 \mathrm{~km}$ at a rate of $\sim 0.4 \mathrm{~mm} \mathrm{yr}^{-1}$. Given that the rate of hanging wall subsidence is not known, it is difficult to assess the total fault throw rate from such results. However, given the uncertainty involved in most methods that are devoted to quantifying fault slip rates, we consider that this value is compatible with the mean throw rate of $1 \mathrm{~mm} \mathrm{yr}^{-1}$ obtained by our method for the central and northern parts of the Barguzin basin.

[31] The nonzero $y$ axis intercept of regression models on the total throw versus throw rate scatter diagrams (Figure 6) is also an interesting feature of the data. It suggests that in some cases, such as in the Barguzin and Muya basins, significant range front relief could have existed prior to scarp rejuvenation by active tectonics in post-Miocene times. In the case of the Barguzin basin, the Late Cretaceous to Paleocene phase of denudation evidenced by apatite fission track models is interpreted as being the result of postorogenic collapse after the late Jurassic-Cretaceous closure of the Mongol-Okhotsk Ocean [Jolivet et al., 2009]. Although it is only possible to speculate over the meaning of these outliers, paleorelief prior to scarp rejuvenation could have existed either because of high rock resistance to denudation in the Barguzin footwall upland or because drainage systems, perhaps poorly integrated in this area between Paleocene and Pliocene times, failed to cause deep denudation prior to the resumption of extensional tectonics circa 3 Myr.

[32] To summarize, the method presented and tested in this study should help in unraveling the long-term, mean velocity of normal faults, keeping in mind that some sources of uncertainty exist. First among these is lithology, which influences bedrock response to erosion: it is recommended that a large number of triangular facets be measured on each individual fault segment, particularly when lithology varies along strike. Second, climatic variations, which according to numerical model trials should exert only limited influence on the height and slope of faceted spurs [Petit et al., 2009], will have an effect when the study area has been covered by glaciers. Fortunately, the imprint of valley and cirque glaciations appears very weak in this area, where the most distinct features are V-shaped valleys incising the footwall blocks of the NBR (Figure 2). Third, the accuracy of facet measurements depends on DEM resolution. Low-resolution DEMs will tend to smooth the topography, resulting in lower facet heights but with an apparent lower uncertainty (smaller standard error). We consider that with the $90 \mathrm{~m}$ resolution of the SRTM database, it is not reasonable to consider facets with heights smaller than $150 \mathrm{~m}$. Given that those small facets are also characterized by low slope angles (about $20^{\circ}$ ), the horizontal fault-perpendicular distance between fault trace and facet top is about $350 \mathrm{~m}$, i.e., 4 pixels in the SRTM model. We also avoided measuring facets close to fault segment tips, where facets are smaller than average because of a younger fault age (propagation) and/or a smaller throw rate. Finally, this method is valid only where the fault-related origin of faceted spurs is beyond doubt. Indeed, conditions in which triangular faceted spurs form are nonunique, and they can result from purely erosional processes (i.e., at the intersection between an inactive front or incised valley and strike-perpendicular drainages). However, on the basis of existing studies of morphotectonics, seismicity, and basin stratigraphy, there is no evidence to support such a scenario in the North Baikal setting.

\section{Conclusion}

[33] This study in tectonic geomorphology of the BRS demonstrates that, on average, triangular facets of the North Baikal Rift display similar slope-to-height ratios as those obtained numerically from coupled surface process and tectonic models. This allows us to directly infer long-term fault throw rates, which are difficult to constrain accurately in most settings, from simply measured values of mean facet height. Long-term throw rates of the North Baikal Rift faults range between 0.2 and $1.2 \mathrm{~mm} \mathrm{yr}^{-1}$, with faster rates in the Barguzin basin. The cumulated throw measured at normal fault scarps appears linearly correlated with the fault throw rate, which suggests that most basins of the North Baikal Rift began to form at the same time, i.e., around 3.2 Ma. Despite larger uncertainties when individual basins are considered, the age of individual basins can nevertheless be estimated and varies from late Miocene ( $~ 8 \mathrm{Ma}$ ) for the North Baikal basin to Pleistocene ( $\sim 1 \mathrm{Ma})$ for the Muya basin. All other basins have a mid-Pliocene age. Fault throw rates are on average lower than those estimated from offset Holocene terraces [San'kov et al., 2000], and the history of basin initiation compares well with the sedimentary sequence of Lake Baikal [Hutchinson et al., 1992; Logatchev and Zorin, 1992; Moore et al., 1997; Kuzmin et al., 2000]. The rapid uplift of the Barguzin fault footwall since $\sim 3 \mathrm{Ma}$ is consistent with the cooling history inferred from apatite fission track analysis 
[Jolivet et al., 2009]. Model predictions perform accurately when compared to radiometrically determined passive deformation rates of landforms and sedimentary units.
[34] Acknowledgments. We thank two anonymous referees for their constructive comments on the manuscript. The authors acknowledge support from the INSU "Action Incitatives" program and from the University of Paris 6 .

\section{References}

Armstrong, P. A., A. R. Taylor, and T. A. Ehlers (2004), Is the Wasatch fault footwall (Utah, United States) segmented over million-year time scales?, Geology, 32, 385-388, doi:10.1130/G20421.1.

Attal, M., G. E. Tucker, A. C. Whittaker, P. A. Cowie, and G. P. Roberts (2008), Modeling fluvial incision and transient landscape evolution: Influence of dynamic channel adjustment, J. Geophys. Res., 113, F03013, doi:10.1029/2007JF000893.

Braun, J., and M. Sambridge (1997), Modelling landscape evolution on geologic time scales: A new method based on irregular spatial discretization, Basin Res., 9, 27-52, doi:10.1046/j.13652117.1997.00030.x.

Brown, E. T., D. L. Bourlès, B. C. Burchfiel, Q. Deng, J. Li, P. Molnar, G. M. Raisbeck, and F. You (1998), Estimation of slip rates in the southern Tien Shan using cosmic ray exposure dates of abandoned alluvial fans, Geol. Soc. Am. Bull., 110, 377-386, doi:10.1130/0016-7606(1998)110<0377:EOSRIT> 2.3. $\mathrm{CO} ; 2$.

Calais, E., M. Vergnolle, V. San'kov, A. Lukhnev, A. Miroshnitchenko, S. Amarjargal, and J. Déverchère (2003), GPS measurements of crustal deformation in the Baikal-Mongolia area (1994-2002): Implications for current kinematics of Asia, J. Geophys. Res., 108(B10), 2501, doi:10.1029/2002JB002373.

Carretier, S., B. Nivière, M. Giamboni, and T. Winter (2006), Do river profiles record along-stream variations of low uplift rate?, J. Geophys. Res., 111, F02024, doi:10.1029/2005JF000419.

Cowie, P. A., A. C. Whittaker, M. Attal, G. Roberts, G. E. Tucker, and A. Ganas (2008), New constraints on sediment-flux - dependent river incision: Implications for extracting tectonic signals from river profiles, Geology, 36, 535-538, doi:10.1130/G24681A.1.

Cunningham, W. D. (2001), Cenozoic normal faulting and regional doming in the southern Hangay region, central Mongolia: Implications for the origin of the Baikal Rift province, Tectonophysics, 331, 389411, doi:10.1016/S0040-1951(00)00228-6.

Ellis, M. A., A. L. Densmore, and R. S. Anderson (1999), Development of mountainous topography in the Basin Ranges, USA, Basin Res., 11, 21-41, doi:10.1046/j.1365-2117.1999.00087.x.

Hutchinson, D. R., A. J. Golmshtok, L. P. Zonenshain, T. C. Moore, C. A. Scholtz, and K. D. Klitgord (1992), Depositional and tectonic framework of the rift basins of Lake Baikal from multichannel seismic data, Geology, 20, 589-592, doi:10.1130/ 0091-7613(1992)020<0589:DATFOT $>2.3 . C O ; 2$

Jolivet, M., T. De Boisgrollier, C. Petit, M. Fournier, V. A. San'kov, J.-C. Ringenbach, L. Byzov, A. I. Miroshnichenko, S. N. Kovalenko, and S. V. Anisimova (2009), How old is the Baikal Rift Zone? Insight from apatite fission track thermochronology, Tectonics, 28, TC3008, doi:10.1029/ $2008 \mathrm{TC} 002404$.
Kashik, S. A., and V. N. Masilov (1994), Main stages and palaeogeography of Cenozoic sedimentation in the Baikal Rift System (eastern Siberia), Bull. Cent Rech. Explor. Prod. Elf Aquitaine, 18, 453-461.

Kooi, H., and C. Beaumont (1994), Escarpment evolution on high-elevation rifted margins: Insights derived from a surface processes model that combines diffusion, advection, and reaction, $J$. Geophys. Res 99, 12,191-12,209, doi:10.1029/94JB00047.

Kozaci, O., J. Dolan, R. Finkel, and R. Hartleb (2007), Late Holocene slip rate for the North Anatolian fault, Turkey, from cosmogenic ${ }^{36} \mathrm{Cl}$ geochronology: Implications for the constancy of fault loading and strain release rates, Geology, 35, 867-870, doi:10.1130/G23187A.1.

Kuzmin, M. I., E. B. Karabanov, A. A. Prokopenko, V. F. Gelety, V. S. Antipin, D. F. Williams, and A. N. Gvozdkov (2000), Sedimentation processes and new age constraints on rifting stages in Lake Baikal Results of deep-water drilling, Int. J. Earth Sci., 89, 183-192, doi:10.1007/s005310000090.

Logatchev, N. A., and N. A. Florensov (1978), The Baikal system of rift valleys, Tectonophysics, 45 , 1-13, doi:10.1016/0040-1951(78)90218-4.

Logatchev, N. A., and Y. A. Zorin (1992), Baikal Rift zone: Structure and geodynamics, Tectonophysics, 208, 273-286, doi:10.1016/0040-1951(92)90349-B.

Lysak, S. V. (1978), The Baikal Rift heat flow, Tectonophysics, 45, 87-93, doi:10.1016/0040-1951(78) 90226-3.

Malitch, N. S., (Ed.) (1999), Geological map of Siberian platform and adjoining areas (in Russian), scale 1:1500000, A. P. Karpinsky All-Russ. Inst. of Geol. Res., St. Petersburg.

Mats, V. D. (1993), The structure and development of the Baikal Rrift depression, Earth Sci. Rev., 34, 81-118, doi:10.1016/0012-8252(93)90028-6.

Meyer, B., and K. Le Dortz (2007), Strike-slip kinematics in central and eastern Iran: Estimating fault slip rates averaged over the Holocene, Tectonics, 26, TC5009, doi:10.1029/2006TC002073.

Moore, T. C., K. D. Klitgord, A. J. Golmshtok, and E. Weber (1997), Sedimentation and subsidence patterns in the central and north basins of Lake Baikal from seismic stratigraphy, Geol. Soc. Am Bull., 109, 746-766, doi:10.1130/0016-7606 (1997) $109<0746$ :SASPIT $>2.3$. CO 2 .

O'Callaghan, J. F., and D. M. Mark (1984), The extraction of drainage networks from digital elevation data, Comput. Vision Graphics Image Process., $28,328-344$

Okada, Y. (1985), Surface deformation to shear and tensile faults in a half-space, Bull. Seismol. Soc. Am., $75,1135-1154$

Parfenov, L. M., B. M. Koz'min, V. S. Imayev, and L. A. Savostin (1987), The tectonic character of the Olekma-Stanovoy seismic zone, Geotectonics, Engl. Transl., 21, 560-572.
Petit, C., and J. Déverchère (2006), Structure and evolution of the Baikal Rift: A synthesis, Geochem. Geophys. Geosyst., 7, Q11016, doi:10.1029/ 2006GC001265.

Petit, C., and M. Fournier (2005), Present-day velocity and stress fields of the Amurian Plate from thin-shell finite-element modelling, Geophys. J. Int., 160 , 358-370, doi:10.1111/j.1365-246X.2004.02486.x.

Petit, C., Y. Gunnell, N. Gonga-Saholiariliva, B. Meyer, and J. Seguinot (2009), Faceted spurs at normal fault scarps: Insights from numerical modeling, J. Geophys. Res., 114, B05403, doi:10.1029/ 2008JB005955.

Ritz, J.-F., E. T. Brown, D. L. Bourlès, H. Philip, A. Schlupp, G. M. Raisbeck, F. Yiou, and B. Enkhtuvshin (1995), Slip rates along active faults estimated with cosmic-ray-exposure dates: Application to the Bogd fault, Gobi-Altaï, Mongolia, Geology, 23, 1019-1022, doi:10.1130/00917613(1995)023<1019:SRAAFE $>2.3$.CO;2.

San'kov, V., J. Déverchère, Y. Gaudemer, F. Houdry, and A. Filippov (2000), Geometry and rate of faulting in the North Baikal Rift, Siberia, Tectonics, 19 , 707-722, doi:10.1029/2000TC900012.

van der Woerd, J., Y. Klinger, K. Sieh, P. Tapponnier, F. J. Ryerson, and A.-S. Mériaux (2006), Long-term slip rate of the southern San Andreas Fault from ${ }^{10} \mathrm{Be}-{ }^{26} \mathrm{Al}$ surface exposure dating of an offset alluvial fan, J. Geophys. Res., 111, B04407, doi:10.1029/ 2004JB003559

Weldon, R., and K. Sieh (1985), Holocene rate of slip and tentative recurrence interval for large earthquakes on the San Andreas Fault, Cajon Pass, southern California, Geol. Soc. Am. Bull., 96, 793-812, doi:10.1130/0016-7606(1985)96<793:HROSAT> 2.0.CO;2.

Whittaker, A. C., M. Attal, P. A. Cowie, G. E. Tucker, and G. Roberts (2008), Decoding temporal and spatial patterns of fault uplift using transient river long profiles, Geomorphology, 100, 506-526, doi:10.1016 j.geomorph.2008.01.018.

N. Gonga-Saholiariliva and Y. Gunnell, Laboratoire de Géographie Physique, UMR 8591, CNRS, 1 Place A. Briand, F-92195 Meudon CEDEX, France. (gonga. saholiariliva@gmail.com; gunnell@paris7.jussieu.fr)

M. Jolivet, Géosciences Rennes, UMR 6118, Université de Rennes 1, CNRS, Bâtiment 15, Campus de Beaulieu, CS 74205, F-35042, Rennes CEDEX, France. (marc.jolivet@univ-rennes1.fr)

B. Meyer, C. Petit, and V. Strak, ISTEP, Université Paris 6, Boîte 129, 4 Place Jussieu, F-75252 Paris CEDEX 05, France. (bertrand.meyer@umpc.fr; carole. mariani@umpc.fr)

V. San'kov, Institute of the Earth's Crust, Russian Academy of Sciences, 128 Lermontov St., Irkutsk 664033 Russia. (sankov@crust.irk.ru) 